\title{
Internationalisation of Artisanal and Small Scale Mining in Ghana: Opportunities and Challenges*
}

\author{
${ }^{1}$ G. Agyei \\ ${ }^{1}$ University of Mines and Technology, P.O. Box 237, Tarkwa, Ghana
}

Agyei , G. (2016) "Internationalisation of Artisanal and Small Scale Mining in Ghana: Opportunities and Challenges", Ghana Mining Journal, Vol. 16, No. 2, pp. 20 - 27.

\begin{abstract}
The last few years have witnessed internationalisation of small scale mining in Ghana. The entry of migrant artisanal miners has brought losers and winners in the subsector, creating myriad of socio-political problems. However, official attempts to curb it have exacerbated the systemic problem of mineral governance. This paper analyses the emerging challenges and opportunities posed by the entrance of migrant miners into the country with insights into assumptions on resources and conflicts. It takes a closer look at the causes, effects and dynamics of confrontation and collaboration between migrant artisanal and small scale miners and their counterparts in the host nation. It argues that the current governance system of small scale mining based on national control over exploitation is anachronic and not well adapted to competitive, sustainable and fair management of mineral resources. In addition, it proposes a sustainable partnership to harness complimentary skills in order to avoid deepening the resources conflicts which have plagued the mining districts.
\end{abstract}

Keywords: Internationalisation, Artisanal, Small Scale Mining, Sustainability

\section{Introduction}

There is a plethora of literature on Artisanal and Small Scale Mining (ASM) which provides an indepth analysis of the impacts, livelihoods and concerns of the various stakeholders (Bachirigah and Hilson, 2008; Hilson, 2002; Hilson and Garforth, 2012). ASM is the main source of income in many rural communities in Ghana. The socioeconomic impact of it is so great that it constitutes full-time employment for both skilled and unskilled people. It is estimated that about 200,000 workers, representing $80 \%$ of the country's mining labour force are in the subsector (Hentchel et al., 2003). Amankwa and Anim-Sackey (2007) propose the concepts of sustainability to small scale mining.

In spite of the legal frameworks and proposals to promote artisanal and small scale gold mining for sustainable development, there is a proliferation of illegal gold mining in all the mining districts of Ghana. Hilson and Garforth (2012) argue that the failure of agriculture policies and overdependence on traditional subsistence farming have contributed to increased ASM activities. The unbridled desire to get rich at the margins of law and order has reached disproportionate levels attracting crossborder miners from different parts of the world. The porous nature of the borders of Ghana and the easy access to free milling gold ores have invited increasing numbers of migrant miners from Burkina Faso, Togo, Ivory Coast, Nigeria, Latin America and Asia. The migrant miners are nomads who move from one site to another, depending on the availability of gold ores. It is a paradox that their main collaborators are the village chiefs and Ghanaian miners. The earnings are shared among the workers and unofficial royalty is paid to the chief to secure a form of social license. A reason for coming to Ghana is that earnings are higher than what would be achieved in home countries or what would be accrued from agriculture.

The onset of "international galamsey" has changed the dynamics and the landscape of small scale and artisanal mining in the last decades. The intensive mechanisation introduced by Chinese miners has increased output and productivity with challenges and opportunities for all the stakeholders. Mr. Sulemana Koney, the Chief Executive Officer of the Ghana Chamber of Mines, said that, "research shows that in most areas where illegal mining takes place, it is usually done largely by non-indigenous persons," (Anon., 2014a). At a panel discussion, Prof. Chris Gordon of Institute of Environment and Sanitation Studies, reiterated that, "few people, out of greed, are making Ghana to lose its natural resources," (Anon., 2014b). Though these assertions may be exaggerated, they uncover the frustrations and the deeply rooted nationalistic sentiments perpetuated by the presence of illegal migrant miners. These sudden and dramatic changes have generated debate about the need to review for categorisation of the ASM subsector into Artisanal, Small Scale Mining (SSM) and Medium Scale Mining (MSM), and enact the appropriate policy guidelines for effective and efficient operations. The geopolitical influence of China and Foreign Direct Investment (FDI) from the "Asian Giant" is vital for Ghana in the context of the present global financial crises where financial assistance from Western development partners continues to slump. Migrant miners from China exert a lot of influence in the mining 
communities. Hence the need to harmonise the current internationalisation of mining with the national regulatory frameworks for competitive and sustainable relationship.

As at 2015 , it was estimated that about $95 \%$ of all miners in the subsector were operating at the margins of the laws. This has resulted in conflicts in the communities, official crackdown and militant contestation against officialdom. There is enormous bad press about the migrant miners, thus, objective literature about their impact on the host nation is limited and insufficient.

The purpose of the paper is to bring to the attention of policy makers and regulators, the need to adopt measures aimed at regulating the activities of migrant miners and protecting the local communities against the negative impacts of mining. In this paper, a 360-degree strategy analysis for artisanal and small scale mining reveals possible increased value through dynamic partnerships. By using a SWOT matrix analysis, the paper confirms that the level and capacity of cooperation among communities, mass media, investors, the state and other stakeholders are key success factors for consensus building in mineral resource management.

\section{Resources and Methods Used}

\subsection{Theoretical Underpinnings}

Spontaneous gold rush is not a new phenomenon of mining in Ghana. It is often argued that, instead of fulfilling the hopes of economic prosperity, gold rush usually dilutes indigenous culture and disrupts the social fabric of the affected communities due to unsustainable patterns of extraction. Several empirical evidences elucidating the connection between mineral exploitation and conflict have been expounded in Le Billon (2010). Rosser (2006) also examines the hypothesis of resource curse which posits that community endowed with mineral resources is likely to experience negative economic, social and political outcomes including social rife. However, Ross (2006) contrasts that those resources are not necessary and sufficient conditions for conflicts in resource-rich communities. The conflicts can be attributed to underdevelopment, poverty, corrupt governance and weak public institutions which had existed as the precursor of those problems. The resultant associated conflicts and the perceived overwhelming negative socio-political impacts on resource-rich countries are well documented (Thornton, 2014). Ghana, the country under focus, is the second largest producer of gold in Africa. The small scale and artisanal gold mining were not regulated in the country until the introduction of the Small Scale Mining Project in 1989. This initiative provided legal and institutional standards for the artisanal and small scale mining. Prior to that period there existed the tributary system for the diamond mining, which made provision for the host communities for mining carved out areas of concessions of the larger mining companies under agreed terms.

The introduction of PNDC Decree Law 218 to regulate the subsector came at a time Ghana was going through austerity and neoliberal structural adjustment reforms recommended by the Bretton Woods Institutions as a precondition for loans and grants to prevent the malfunctioning economy from total collapse. The main goal was to create business opportunities for the retrenched workers from the divested state-owned enterprises. The policy was intended to contribute to mitigating the social cost of the structural adjustment process. The project also aimed at regulating the trade in gold and diamond, thus reducing smuggling. Proponents of small scale and artisanal mining argue that the subsector has a greater potential to provide foreign exchange and alleviate poverty than farming; since it attracts both unskilled and skilled workforce in the rural areas than any other economic activity. However, the initial implementation of the project suffered from strategic planning, favouritism and exclusion of some key stakeholders like the village chiefs. The people who felt they had some legitimate rights to mine gold because of the ancestral land tenure system, but felt marginalised, used their own means to get access to the resources without recourse to the promulgated mining laws. The causes of antagonistic relationships arising from the struggle to control the resources between social actors in small scale and artisanal mining are well documented (Labonne, 2014, Hilson \& Mcquilken, 2014).

\subsection{Methodological Insights}

In this paper, mineral resources and conflicts framework with insights into stakeholder theory analyses are used to explain the new trend of internationalisation of artisanal and small scale gold mining and its implications. The sudden upsurge in mining activities by foreign nationals in the last few years has been received with mixed feelings. Though some remarkable improvements have been attributed to the high influx of migrant miners, violent confrontations between the host communities and the expatriate illegal miners have been recorded in mainstream media. The higher productivity levels introduced by uncontrolled modern mechanised mining methods have been achieved with serious environmental and social costs which undermine the subsector as a contributor to economic development. The precarious working conditions, unsustainable systems of mineral extraction, and environmental degradation have resulted in truculent relationships 
between the miners and the state. Though about $80 \%$ operate under unregulated conditions, their operations have offered employment opportunities and unaccounted direct foreign capital injections into the economy. However, externalities of significant social concerns identified are cultural clashes leading to social unrest, child labour, prostitution and human trafficking. Competition for space between farming and mining has intensified more than ever. Instead of bringing opportunities for farmers to get ready markets for their produce due to the high influx of migrant miners to the forest belt, the increase in mining activities has rather dislodged many farmers leading to violent clashes between farmers and the miners. These new dynamics have also brought food insecurity and pressure on limited accommodation in the mining villages. The prevailing condition corroborates some of the arguments of Cuvelier et al. (2014) which expound a critical analysis of a causal relationship between resource abundance and conflicts.

At the national level, internationalisation of small scale mining has been politicised, leading to tensions between the dominant political parties, each trying to gain the maximum political capital out of the situation. In an online discussion (Anon., 2015) Da Real Blackman said, "What is the government doing to stop this menace to our environment, and the rampant disregard of our laws by illegal aliens? They are stealing our resources and the government is doing nothing about it! Can Ghanaians or Africans for that matter go to China and engage in activities such as these? Wake up, Africans!"

The trading of accusations and counter accusations extend to all power centres of governance to the extent that even the security agencies are said to be paid off by the Chinese miners. Collusion between the state and the Chinese miners has also been speculated. At Ayanfuri, Ama, a young student warned, "If the government does not do anything about these migrant miners, I will vote against them in the 2016 elections! Why?" However, Mr.Kwaku Abedu, Director of Johnson Mining Services, a licensed small scale mining company located at Tarkwa affirmed that, "The arrival of the Chinese has helped small scale mining. The major problem we have here is lower gold recovery rates in processing. The Chinese are helping to solve recovery problems. We wouldn't have got new technologies for milling and processing without the Chinese. After 30 years of Small Scale Mining Law, what have we done as a nation to improve it? Thanks to the Chinese we have Changfa (impact crusher) and others at affordable prices. We need them here".

It is also alleged that these mining activities are financed by the mafia and barons who do not reside in the country. Faced with open criticism from environmentalists and other pressure groups from within and outside the country for failing to protect fragile ecosystems and rivers, the government was compelled to crackdown on those adamant illegal miners 2014. A joint operation by the army, the police and other state institutions coordinated actions to violently confiscate equipment in a nationwide operation. Subsequently, thousands of Chinese miners were deported.

Resources and conflict approach is proposed in this paper for amicable resolution because sustainable development cannot thrive in resource-rich areas in the midst of conflicts. In search for a compromised solution to a conflict, both sides must also recognise the legitimate demands of each contender. It is generally argued that the incessant crackdown on migrant miners has not achieved the intended goal because of inappropriate approach. The excessive use of force to evict Chinese nationals rather fomented strained relations between Accra and Beijing (Hess and Aidoo, 2015). China is an important trade ally and creditor of Ghana. Consequently, the country had to tread on a tightrope between deporting the illegal miners to lose grants from China, and allowing the miners to devastate the environment and face the wrath of the host communities.

Interviews were conducted in the mining districts. Focal discussions were systematically conducted with miners, students and academia in Tarkwa, Esuoso, Nsuaem, Ayanfuri, Dunkwa, Diaso, New Edubiase, Obuasi, Bekwai, Gyakubu and Manso Nkwanta between November 2015 and February 2016. Many of the interviews were semi-structured and open ended to allow the interviewees to freely express their opinions and perspectives. This methodology is based on the author's direct experience in the mining districts for eight years. First-hand information was obtained by frequently interacting with migrant miners. The author has spent several years here observing the activities of small scale and artisanal miners. The author has worked on several committees in the Tarkwa Nsuaem Municipal Assembly and has directly participated in small scale mining conference proceedings and consulted several government documents on the issue.

\subsection{Study Area}

Tarkwa and Dunkwa mining districts of the Minerals Commission of Ghana are located in the Western and Central regions respectively. The study was conducted in the following political and administrative towns: Tarkwa, Esuoso, Nsuaem, Ayanfuri, Dunkwa, Diaso, New Edubiase, Obuasi, Bekwai, Gyakubu and Manso Nkwanta. The area falls within the semi-deciduous and evergreen dissect plateau of about $250 \mathrm{~m}$ above sea level. The 
major rivers in the area polluted by galamsey are Offin, Pra and Bonsa.

The favourable petrographic conditions, and the existence of Birimian and Tarkwaian gold bearing rock formations have resulted in gold belts series, which have produced widespread small scale mining activities in the area. As a result of weathering processes, significant portions of the rocks have been denuded and deposited as placer formations. Large deposits of placer gold are found in the flood plains, terraces and river beds of Offin, Pra, Bonsa, Ankobra, and Tano rivers where the supercrustal rocks have experienced intense weathering and subsequent deposition, making the area an important source of free milling ores which are amenable to small scale mining rudimentary technologies. Mining practice involves the use of locally manufactured tools such as pick- axes, shovels, hammers, chisels, mattocks, buckets and wheelbarrows. Miners in underground mines combine rudimentary and modern tools to perform labour intensive, time consuming and hazardous work. Groups of men, women and children team up to work for about 12 hours a day digging adits and shafts, using homemade pulleys, head pans and buckets to haul up ore and pound it in mortars or grind them in corn mills, and impact crushers.

Highly mechanised heavy duty equipment like hydraulic excavators, bulldozers and dump trucks are also used. Mineral processing techniques involve the use of hand operated jigs, pans and sluice boards. Advanced methods apply trommels, shaking tables and other advanced gravity concentrators.

\section{Results and Discussion}

\subsection{Intra-Industry Dynamics or "The Confusion"}

The involvement of foreign nationals in small scale and artisanal mining has brought some visible positive impacts in the host communities. There has been substantial injection of foreign direct capital into the sector through intensive expenditure on materials and equipment; improved methods of mining have also been an added advantage of the presence of migrant miners. External participation has contributed to the economic diversification of the local communities. Modern amenities such as hospitals, hotels and supermarkets owned and operated by Chinese are found in Tarkwa, Dunkwa, Ayanfuri and others evidencing direct positive impacts of foreign miners to the mining communities. The multiplier effects of these economic activities cannot be overemphasised. The Chinese have highly mechanised forms of mining and mineral processing. The versatile and popularly known changfa and other machines in the mining districts are good examples of the contribution of foreign miners to the development of mining and transfer of technology. Many registered small scale miners have formed joint ventures with Chinese nationals, resulting in the mutual transfer of skills and technology. A setback to the celebrated positive impact of migrant miners is their alleged involvement in the introduction and unauthorised widespread use of cyanide in gold leaching processes in Tarkwa, Bibiani, Bawdie and Dunkwa (Anon., 2010). The police have arrested and prosecuted some of the foreigners, mostly Burkinabe nationals. Cyanide is very toxic and any careless operation can lead to a serious disaster.

In some cases the Chinese have illegally acquired concessions and operate their own mines. Though the mergers and acquisitions with the Chinese have recapitalised the small scale mining sector in times of serious financial crises and fluctuating gold prices, they ought to be regularised in order to create more opportunities for economic growth. The tailings produced by higher production rates also benefit some large mining operations in the supply chain, leading to new structural linkages among various stakeholders.

The small scale miners are unable to reach recoveries beyond $15-50 \%$ with the gravity concentration methods. Consequently, the lower recovery indices make their tailings products important feedstocks for large operations, which apply state of the art cyanidation to leach gold. For example, Perseus Mining Ltd. and Golden Star Wassa Resources are supplied with large tonnages of tailings from the small scale mining operations in the study area. Dozens of trucks haul the waste materials from small scale and artisanal mining sites to several large scale multinational mining companies (Anon., 2016). The residues were previously sold at lower prices as construction materials. This new exchange relationship propitiated by high mechanisation helps to achieve production efficiency for both large and small operations. As a result of the transactions in tailings, new business entities, which buy and haul the residues to the large mining operations have sprung up. These new trends need further studies to determine proper policy formulations for sustainable development. Table 1 gives a SWOT analysis of the various stakeholders which may help take appropriate decisions to improve their participation. 
Table 1 SWOT Analysis of Exploitation of Small Scale Gold Mining in Ghana (adapted from Pina, 2015)

\begin{tabular}{|c|c|c|c|c|}
\hline & Strengths & Weakness & Opportunities & Threats \\
\hline 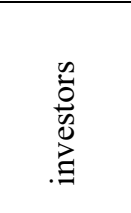 & Considerable capital & $\begin{array}{l}\text {-Susceptible to bad } \\
\text { press manipulation } \\
\text {-Not provided with } \\
\text { clear mining and } \\
\text { business laws }\end{array}$ & $\begin{array}{l}\text { Knowledge about } \\
\text { the presence of } \\
\text { human capital who } \\
\text { may collaborate or } \\
\text { compete with them }\end{array}$ & $\begin{array}{l}\text { A country risk } \\
\text { assessment profile } \\
\text { may divert } \\
\text { investors in other } \\
\text { countries }\end{array}$ \\
\hline 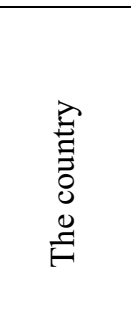 & $\begin{array}{c}\text {-Mineral rights } \\
\text { - Interest in economic } \\
\text { diversification }\end{array}$ & $\begin{array}{c}\text {-Lack of } \\
\text { coordination } \\
\text { between various } \\
\text { arms of government } \\
\text { on ASM } \\
\text {-Corruption in } \\
\text { public } \\
\text { administration }\end{array}$ & $\begin{array}{c}\text { Sustainable } \\
\text { management of } \\
\text { mineral resources }\end{array}$ & $\begin{array}{l}\text { Growing negative } \\
\text { perception in the } \\
\text { international } \\
\text { business circles }\end{array}$ \\
\hline 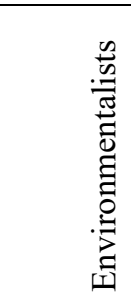 & Authoritative information & $\begin{array}{l}\text { Lack resources to } \\
\text { evaluate all the } \\
\text { areas affected by } \\
\text { mining }\end{array}$ & $\begin{array}{c}\text {-Prove that mining } \\
\text { is compatible with } \\
\text { the environment } \\
\text {-Show that mining } \\
\text { is compatible with } \\
\text { human } \\
\text { development }\end{array}$ & $\begin{array}{c}\text { The rapid growth in } \\
\text { economic activities } \\
\text { makes } \\
\text { comprehensive } \\
\text { environmental audit } \\
\text { difficult }\end{array}$ \\
\hline $\begin{array}{l}: \frac{\pi}{0} \\
\stackrel{\Xi}{0} \\
\infty \\
\tilde{E}\end{array}$ & Wider audience & $\begin{array}{l}\text { Manipulation of } \\
\text { news and } \\
\text { misinformation by } \\
\text { sections of the } \\
\text { media }\end{array}$ & $\begin{array}{l}\text {-Objectively } \\
\text { broaden the mining } \\
\text { discourse } \\
\text {-Educate the miners }\end{array}$ & $\begin{array}{l}\text { The possibility of } \\
\text { false information } \\
\text { which may not help } \\
\text { build consensus }\end{array}$ \\
\hline 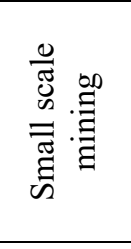 & Legal by Act 703 & $\begin{array}{l}\text { A complex license } \\
\text { procedure not } \\
\text { easily accessible }\end{array}$ & $\begin{array}{c}\text { Improved } \\
\text { organisation can } \\
\text { lead to better } \\
\text { working standards } \\
\text { and technical } \\
\text { solutions } \\
\end{array}$ & $\begin{array}{c}\text { Many operate } \\
\text { without recourse to } \\
\text { environmental and } \\
\text { labour standards }\end{array}$ \\
\hline i & $\begin{array}{l}\text { - Numerical strength } \\
\text { - Economically diverse groups }\end{array}$ & $\begin{array}{l}\text {-Lack of public } \\
\text { services } \\
\text { - Low levels of } \\
\text { education }\end{array}$ & $\begin{array}{l}\text { Position themselves } \\
\text { to improve their } \\
\text { standard of living }\end{array}$ & $\begin{array}{c}\text { Remoteness of } \\
\text { some settlements } \\
\text { makes it difficult to } \\
\text { understand specific } \\
\text { issues }\end{array}$ \\
\hline 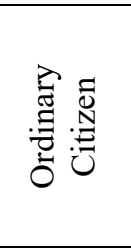 & $\begin{array}{l}\text { Knowledge about mining and } \\
\text { how it affects national life }\end{array}$ & $\begin{array}{l}\text { People outside the } \\
\text { mining communities } \\
\text { have negative } \\
\text { perception }\end{array}$ & $\begin{array}{c}\text { The potential } \\
\text { benefits of small } \\
\text { scale and artisanal } \\
\text { mining and how to } \\
\text { interact with it }\end{array}$ & $\begin{array}{c}\text {-Manipulated by } \\
\text { misleading } \\
\text { information } \\
\text { - Negative } \\
\text { perception about } \\
\text { ASM }\end{array}$ \\
\hline 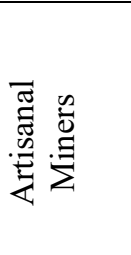 & $\begin{array}{l}\text { The right to participate in } \\
\text { mining }\end{array}$ & $\begin{array}{l}\text { No defined laws to } \\
\text { regulate them }\end{array}$ & $\begin{array}{c}\text { Better organization } \\
\text { can make them law } \\
\text { abiding }\end{array}$ & $\begin{array}{l}\text {-Unregulated } \\
\text { activities tend to } \\
\text { degrade the } \\
\text { environment } \\
\text { - Bad press }\end{array}$ \\
\hline
\end{tabular}




\subsection{Sustainable Solutions and Strategic Planning for the Small Scale Mining Companies}

The high cost of energy and other consumables, the incessant fluctuations in the price of gold in the world market and the macroeconomic instability of Ghana in the context of the global financial crisis compel the small scale mining subsector to find strategic planning as an important tool to be able to be competitive.

Ghana in the context of a globalised, a complex and uncertain world cannot solve the small scale and artisanal mining problems using the old thinking of resource nationalism. Unfortunately, all our views, concepts and laws were made when the world seemed to follow linear orderly patterns. All of a sudden we are faced with contradictions and uncertainties which throw our values and institutions into serious crises. The change from nationally based mining to a globalised network does not make sense to write in the mining law that a license for small scale mining shall not be granted to a person unless the individual is a national of Ghana. The transition from a closed national economy to a globalised one has changed everything to metastable conditions. Laws, concepts and models in the stable world are no more relevant. Instead of using the usual best practices, sustainable and creative solutions must be applied to specific problems. The solutions should be based on pragmatic concepts of Leadership, Entrepreneurship and Management (LEM) profile to generate innovative business solutions as illustrated in Fig.1. Smart institutions must be put in place to respond to quick changes. We cannot continue to interpret our world in the linear, sequential and phased manner. Socioeconomic events in the present context are systemic and asymmetric in nature. Excessive centralization of license acquisition procedure where practically everything is controlled by the Minister in Accra is inefficient.

The state does not create value in the present economy. For this reason, people, who are able to generate and visualise opportunities in the mining sector should be allowed to take ownership of the opportunities, irrespective of their nationalities. This will help attract the necessary resources to get new things done. The alleged looting of resources by foreigners will not hold if proper institutions are put in place to regulate the activities or the system is allowed to regulate itself through market forces.

The 360-degree analysis in Fig. 2 reveals the emerging context which upsets the status quo. It proposes an approach to solving the problem posed by the internationalisation of small scale mining.
The necessary conditions for successful implementation are as follows:

(i) Educating the people in the present dynamic environment to successfully plan for the new challenges and opportunities;

(ii) Anticipating the future;

(iii) Scanning the global scene for best practices for creative adoption and adaptation;

(iv) Creating spin-offs, start-ups, loners or joint ventures;

(v) Linking the unregistered artisanal miners with the SSM/MSM to create clusters or virtual cooperatives;

(vi) Forming collaborative networks;

(vii) Creating banks to support SSM/MSM with special conditions for them; and

(viii) Creating entrepreneurs' foundry in developing new mining entrepreneurs.

The 360- degree strategy analysis model explores the emerging context by screening the strategic weaknesses and strategy execution readiness as follows:

(i) The adjacent quadrants $\mathrm{A}+\mathrm{B}=$ what makes the small scale mining of Ghana unique to attract so many foreigners? What can the Ghanaian small scale mining offer to the world? This combination leads to the question: Is there a gap between the existing conditions and sustainable artisanal and small scale mining? Is Ghana best at something in this sector, which it does not offer? What? Why?

(ii) Opposite quadrants $\mathrm{A}+\mathrm{D}=$ what are the unique skills of Ghana in the field + what are the investors willing to offer for the development of small scale mining for mutual benefits? Do the investors appreciate what the nationals can offer? Are the nationals really skilled in the present small scale mining?

(iii) Adjacent quadrants $\mathrm{A}+\mathrm{C}=$ what are the local miners good at? + What are the foreign investors looking for in the country? How will the small scale mining be in the future?

(iv) The opposite quadrants $\mathrm{B}+\mathrm{C}=$ what can the country offer? + What are the foreign investors aiming at? How well do these two points match international sustainable mining trends? 
ASM needs to be put to the service of the local communities. There is a unique opportunity for sustainable ASM mining. Policy makers must promote corporation for dynamic partnership which allows leveraging the best from all engaged stakeholders to enable the country harness the skills and services of migrant miners.

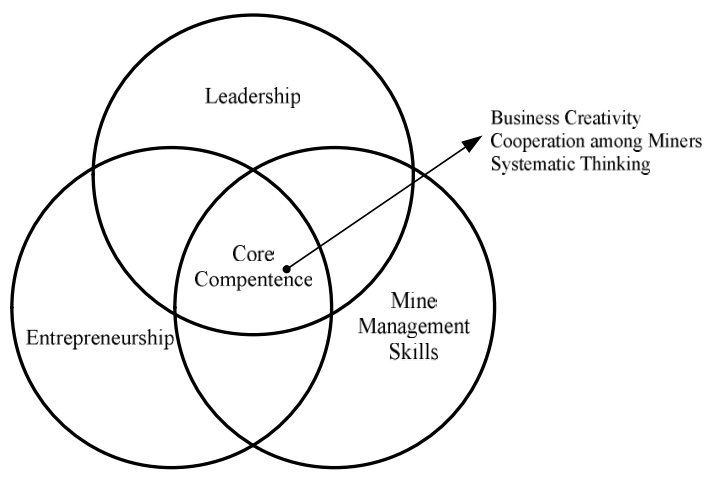

Fig. 1 Leadership, Entrepreneurship and Management (LEM) Profile

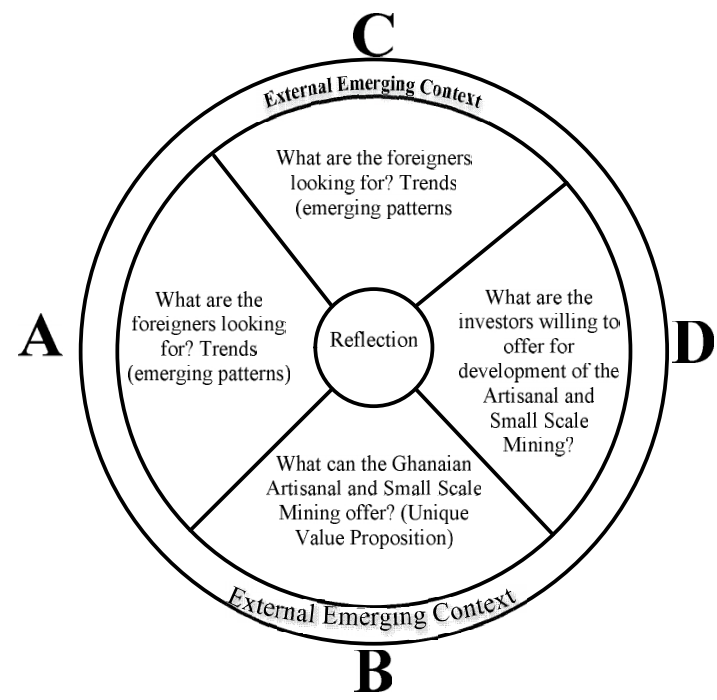

Fig. 2 A 360 -Degree Strategy Analysis

The transition from nationally centred business to internationally focused corporation and partnership model is a "bumping" path. It is limited to the loss of traditional values like "this is our land and this is our mineral". This inevitable change is stakeholder driven. This means that the global engagement is demanded by psychological factors and "smart thinking".

The ASM business in the present economy demands the creation of new business ventures and corporate corporation. Every form of corporation should be leading towards a dynamic partnership, where all involved parties are participating, growing and unleashing their business potentials. The author is of the view that legalising the operations of foreign investors in an orderly manner will lead to increased value. The narrow focus on mineral nationalism for small scale mining has not improved the situation in safety and environmental protection. The people still work under poor labour standards because the state institutions of Ghana have not been able to enforce the labour laws.

The management of small scale sector is replete with policies developed from myopia, false information, intrigues, and poor communication between the stakeholders. These deficiencies are serious impediments towards the implementation of novel business ideas.

A major weakness of Ghana is bad governance perpetuated by corrupt political elite and ineffective public institutions. Those at the helm of affairs do not even think of establishing partnership, but rather prefer to extort money from the Chinese miners as a precondition for them to operate illegally.

Ghana must change its mining laws to reflect the current trend of mining. For example, the qualification of applicant for small scale mining license in Minerals and Mining Act, 2006 (Act 703) Section 83(a) states, "A license for smallscale mining operation shall not be granted to a person unless that person is a citizen of Ghana", and Section 88 states, "A license granted under section 82 (1) may be transferred only to a citizen and with the consent of the Minister". All these inward looking clauses and red tapes do not create the enabling environment towards business creativity in this contemporary fast moving and economically changing world. The government must create the necessary environment for joint ventures, mergers and acquisitions instead of crackdown and confrontation with the migrant miners. Literature on mineral resources and conflicts usually tag all forms of conflict as negative and damaging. However the findings from this study reveal the importance of consensus through bargaining for cooperation and mutual development.

\section{Conclusions}

This paper has outlined the impacts of artisanal and small scale mining and migrant miners in Ghana. The Economic Recovery Program (ERP) implemented in the period of 1982 to 1992 brought significant changes in various sectors of the economy of Ghana. The small scale mining sector was not left out during that momentous macroeconomic restructuring and extractive industry reforms. The promulgation of PNDC Decree Law 218 which was later incorporated in Minerals and Mining Act 703 brought significant changes in the mining landscape. However, the 
swarming of migrant miners to Ghana from 2010 to date has brought opportunities and challenges which must be addressed to prevent conflicts in the local communities.

The paper also has sought to increase our understanding of the effects of internationalisation of artisanal and small scale mining. The findings may help policy makers to enhance the capability of the key stakeholders, recognising that sustainable resource governance is a keystone in helping Ghana in the rational use of mineral resources. The paper proposes a 360-degree systemic, strategic, and stakeholder based, inclusive solutions to existing mining crises by denouncing extreme mineral resource nationalism.

The paper also highlights some deficiencies in the existing mining laws of Ghana with emphasis on the need to categorise mining into small, medium, and large scale mining to satisfy the current exigencies of mining in the country. This paper is relevant to the development of the Mineral Resource Policy of Ghana in general and the small scale mining in particular.

\section{References}

Amankwa, R. K. and Anim- Sackey, C. (2007), "Strategies for sustainable development" for small scale and diamond mining industry in Ghana, Resources Policy 29, pp. 131-138.

Anon. (2006), Minerals and Mining Law, 2006 (Act 703), Ghana Publishing Company Ltd, $59 \mathrm{pp}$.

Anon. (2010), "Foreigners-using Cyanide in Galamsey",http://www.ghananews agency .org /print/19415, Accessed, February 25, 2016.

Anon. (2014a), "Majority of Illegal Miners are Migrants”, ttp://ghanachamberofmines.org /en/ posts/majority-of-illegal-miners-are-migrants--chamber-of-mines-0.php? $\quad p=15$, Accessed, January 11, 2016.

Anon. (2014b), "Majority of Illegal Miners are Migrants",http://www.ghananewsagency.org/so cial/majority-of-illegal-miners-are-migrantschamber-of-mines-83411, Accessed, January 15, 2016.

Anon. (2015), "Chinese Miners Defy Military; Engage in Alluvial Mining", 30/09/2015, http://mobile.ghanaweb.com/wap/article.php?I $D=384799 \&$ mode $=$ comments,$\quad$ Accessed, February 24, 2016.

Anon. (2016), "It's Official: Mining Giants Aiding Galamsey",http://www.modernghana.com/news 669894/its-official-mining-giants-aidinggalamsey.html, Accessed: March 14, 2016.

Bachiringa, S. M. and Hilson, G. (2008), "Challenges with eradicating illegal mining in Ghana: a perspective from the grassroots", Resources Policy, Vol. 33, No.1, pp. 29 - 33.
Cuvelier, J., Vlasenroot, K. and Olin, N. (2014), "Resources, Conflict and Governance: A Review", Extractive Industries and Society, Vol. 1, No. 1, pp. 340 - 350.

Hentchel, T., Aruschka, F. and Priester, M. (2003), "Small Scale and Artisanal Mining: Challenges and Opportunities", MMSD Technical Report, IIED\& WBCSD, 94 pp.

Hess, S., and Aidoo, R. (2015), Charting the Roots of Anti-Chinese Populism in Africa, Springer International Publishing, $250 \mathrm{pp}$.

Hilson, G. (2002), "Land use competition in developing countries: profiling the struggles of Ghana's Galamsey miners", Minerals and Energy, Vol.17, No. 3, pp. 2 - 14.

Hilson, G. and Mcquilken, J. (2014), "Four decades of support for artisan and small scale mining: A critical review", Extractive Industries and Society, Vol.1, No.1, pp. 104 - 118.

Hilson, G., and Garforth, C. (2012), “Agricultural Poverty and expansion of artisanal mining in sub-Saharan Africa", Population Research and Policy Review, Vol. 31, No. 3, pp. 435 - 464.

Labonne, B. (2014), "Who is afraid of Small Scale and Artisanal Mining (ASM)?" Extractive Industries and Society, Vol. 1, No. 2, pp. 121 123.

Le Billon, P. (2010), "The Political Ecology of War: Natural Resources and Conflict", Journal of Political Geography, Vol. 20, No. 5, pp. 261 - 584.

Pina, A.B. (2015). "Data on Mercury in Bolivar State", Unpublished BSc Project, Central University of Venezuela, 27pp.

Ross, M. (2006), “A Closer Look at Oil, Diamond and War", Annual Review of Political Science Vol. 9, pp. 265 - 300.

Rosser, A. (2006), "The Political Economy of the Resource Curse: a Literature Survey", IDS working paper 268, Institute of Development Studies, UK, 88 pp.

Thornton, R. (2014), "Zamazama "illegal” Artisanal Miners Misrepresented by South African Press and Government", Extractive Industries and Society, Vol. 1, No. 2, pp. 127 129.

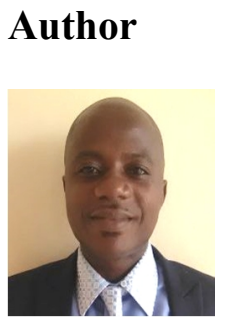

George Agyei is a Senior Lecturer in the Department of Mining Engineering, University of Mines and Technology, Tarkwa. He holds a BEng in Mining Engineering from Moa Higher Institute of Mining and Metallurgy, Cuba, an MBA in General Management from Educatis University, Altdorf, Switzerland and a $\mathrm{PhD}$ in Minerals Beneficiation from the University of Havana, Cuba. His main research interests are Process Mineralogy, Minerals Beneficiation and Sustainable Development. 